\title{
Discrimination Law and the Ebb and Flow of Indirect Effect in Britain
}

\author{
James Hand 1
}

Published online: 6 September 2016

(C) The Author(s) 2016. This article is published with open access at Springerlink.com

\begin{abstract}
Strained judicial interpretation of British discrimination law is not new; some of the leading House of Lords cases on the European Union law doctrine of Indirect Effect have concerned discrimination law. The interpretative obligation, to read national law in line with EU law, has seen words read in and like being treated with like according to changing mores. However, the disability discrimination case of EBR Attridge Law v Coleman [2010] I.C.R. 242 saw an entire sub-section being read in by an Employment Appeal Tribunal. This article briefly reviews the House of Lords' approach in earlier cases, primarily through the prism of discrimination law, and then asks, following more recent Employment Appeal Tribunal cases concerning pregnancy discrimination and the protection from victimisation within the Equality Act 2010, whether the high-water mark for judicial re-writing has been reached in Britain and whether compliance with European law can better be attained in other ways.
\end{abstract}

Keywords Discrimination · EU law · Indirect effect · Equality Act 2010 - Judicial interpretation

Discrimination law and the Ebb and flow of indirect effect in Britain.

James Hand

James.Hand@port.ac.uk

1 School of Law, University of Portsmouth, Richmond Building, Portland Street, Portsmouth PO1 3DE, UK 


\section{Introduction}

British discrimination law has both national and European origins and thus has often been subject to the European doctrine of indirect effect. ${ }^{1}$ Indeed, a number of the leading cases on indirect effect have concerned discrimination law. ${ }^{2}$ The doctrine as laid down by the ECJ in Marleasing SA v Comercial Internacional de Alimentacion $S A^{3}$ requires national legislation to be construed so far as possible to give effect to EU directives, whether or not the national legislation was designed to implement the directive. ${ }^{4}$ This interpretative obligation, with its reference to possibility, goes beyond merely following an EU-compliant construction when there are two equally possible alternatives, but generally not as far as allowing the directive to be followed outside national legislation - the latter being the preserve of directly effective EU legislation. ${ }^{5}$ When seeking to synthesize particular provisions of EU and national law, the task for the national courts is to determine how much the words can tolerably bear and where to draw the line. ${ }^{6}$

This article firstly outlines the approaches previously adopted by the House of Lords regarding the interpretative obligation, primarily in relation to British discrimination law, before going on to consider the more extreme example in Attridge Law v Coleman (where an entire subsection was read into an Act) and then some subsequent developments in both case law and legislation, concerning pregnancy discrimination and victimization. ${ }^{7}$ It will chart the various approaches to interpretation, will consider whether the high-water mark for judicial re-writing has been reached in Britain and will suggest that compliance with European law can otherwise be better attained.

\section{Background: The approach of the House of Lords in Earlier Cases}

The analytic interpretation required by the Marleasing doctrine, outlined above, is not reserved to national legislation which, either explicitly or effectively, implements directives, but also extends to pieces of legislation that cover the same

\footnotetext{
1 'British' (rather than UK) discrimination law is referred to here as Northern Ireland has its own distinct anti-discrimination legislation.

2 Such as Pickstone v Freemans [1989] AC 66 and Webb v EMO Air Cargo [1995] 1 WLR 1454, HL as well as the founding European case of Von Colson \& Anor v Land Nordrhein-Westfalen (C-14/83) [1986] 2 CMLR 430.

3 Marleasing SA v Comercial Internacional de Alimentacion SA (C-106/89) [1991] I-ECR 4135.

${ }^{4}$ Lester (1993) described this case among others as causing our judges to act increasingly as a lawmakers: "Whether we and they like it or not, our judicial lions will have to move from their relatively sheltered position beneath the throne of the sovereign Queen in and outside Parliament".

5 This article focusses on indirect effect and the interpretative obligation and thus will not consider direct effect or Francovich claims for failure to give effect to EU legislation.

${ }^{6}$ Marleasing took the obligation further than Von Colson (which concerned implementing legislation) but some later cases acknowledge that national courts will not always consider themselves able to come to a compliant construction (e.g. Wagner Miret v Fondo de Garantia Salarial Case C-334/92 [1993] ECR I-6911; see further Craig and de Búrca (2011), Steiner and Woods (2009) and Twigg-Flesner (2008)). See also Drake (2005).

7 In doing so it will inevitably have to refer to former pieces of discrimination law as well as the newer Equality Act 2010.
} 
ground as directly effective treaty articles or regulations (as it is recognised that if national law can be read as complying with such European law there is no need to try to invoke the supremacy of the latter). ${ }^{8}$ It is instructive to consider some of the leading authorities before going on to see how they have been applied. The equal pay case of Pickstone v Freemans Plc ${ }^{9}$ is particularly instructive not only because it is an example of the wider use of indirect effect ${ }^{10}$ but also because of there being some divergence regarding the mode of interpretation. In his speech, Lord Templeman noted that the House of Lords had, in the earlier sex discrimination case of Duke v Reliance Systems Ltd ${ }^{11}$ (which concerned a retirement provision that expressly conflicted with the ECJ's interpretation of the Equal Pay Directive), "declined to distort the construction of an Act of Parliament which was not drafted to give effect to a Directive and which was not capable of complying with the Directive as subsequently construed by the European Court of Justice". ${ }^{12}$ The situation in Pickstone, however, was very different as there was no clearly conflicting provision and he thus had

no difficulty in construing the Regulations of 1983 in a way which gives effect to the declared intention of the Government of the United Kingdom responsible for drafting the Regulations and is consistent with the objects of the E.E.C. Treaty, the provisions of the Equal Pay Directive and the rulings of the European Court of Justice. ${ }^{13}$

Lord Oliver, by contrast, originally considered that the wording was not ambiguous and that a literal interpretation would conflict with European law. However, he came to the view that as these regulations were passed to give effect to European obligations under the European Communities Act 1972 they fell into a "special category" for interpretation and, with that in mind, that they were reasonably capable of bearing a meaning which would not put the United Kingdom in breach of its Treaty obligation. ${ }^{14}$ This would be done not so much by "doing

\footnotetext{
${ }^{8}$ As Lord Keith put it in Pickstone v Freemans [1989] AC 66, 112: "In the circumstances it is unnecessary to consider the ground upon which the Court of Appeal found in favour of the respondents, namely that article 119 was directly enforceable in such a way as to enable their claim to be supported irrespective of the true construction of the Regulations of 1983."

9 Pickstone v Freemans Plc [1989] AC 66.

${ }^{10}$ The House of Lords unanimously (after some debate) interpreted national regulations amending the Equal Pay Act 1970 purposively so as to comply with both the source treaty obligation and the mischief that Parliament intended to remedy.

11 Duke v Reliance Systems Ltd [1988] AC 618.

12 Pickstone v Freemans Plc [1989] AC 66, 123. Lord Diplock in Garland v British Rail Engineering Ltd [1983] 2 AC 751 had noted the trite law regarding international treaty obligations that later legislation is to be construed, if it is reasonably capable of bearing such a meaning, as being intended to comply with the obligation and mooted the possibility EC law may require more (at 771). Lord Templeman in Duke, having had advantage of full argument (not available to Lord Diplock) held that the provision in question in both was not designed to implement EC law and that Lord Diplock's proposition did not "enable or constrain a British court to distort the meaning of a British statute in order to enforce against an individual a Community directive which has no direct effect between individuals" (at 639-640).

13 Pickstone v Freemans Plc [1989] AC 66, 123.

14 Pickstone v Freemans Plc [1989] AC 66, 126.
} 
violence to the language of the section as filling a gap by an implication which arises, not from the words used, but from the manifest purpose of the Act and the mischief it was intended to remedy". "Such construction could then be either that adopted by Lord Templeman or through reading into the regulations a seven word parenthetic phrase. ${ }^{16}$ Lord Keith considered, pragmatically, that some implication may be necessary but that " $[\mathrm{t}]$ he precise terms of that implication do not seem to me to matter" and that it was sufficient to construe the words purposively. ${ }^{17}$ The remaining Law Lords on the panel, Lord Brandon and Lord Jauncey, concurred with all three. ${ }^{18}$

The same panel of the House of Lords again considered the interpretation of regulations, this time intended to give effect to a directive (the 'Acquired Rights Directive'), ${ }^{19}$ in the non-discrimination case of Litster and Others v Forth Dry Dock \& Engineering Co. Ltd. (In Receivership) and Another. ${ }^{20}$ As in Pickstone, there were national regulations which were intended to give effect to European law, and as in Pickstone, the wording of a provision allowed (or arguably, viewed literally, mandated) an interpretation which meant they could be readily evaded. The regulation at issue protected the rights of employees when their business was transferred and in doing so referred to those "so employed immediately before the transfer", which on a literal interpretation could exclude those dismissed $1 \mathrm{~min}$ before the transfer. Using the precedent of Pickstone, their Lordships held that words could be implied into the regulation so as to fill the lacuna and achieve a construction consistent with European community law. Lord Keith, in his short concurring speech, took a more emphatic view of Pickstone than he had in the case itself holding that

on a literal reading the regulation particularly relevant did not succeed in completely filling the lacuna. Your Lordships' House, however, held that in

\footnotetext{
15 Pickstone v Freemans Plc [1989] AC 66, 125.

16 Pickstone v Freemans Plc [1989] AC 66, 126; the read in or inserted words being '(in respect of the man hereinafter mentioned)' so that s.1(2)(c) of the Equal Pay Act 1970 would be read as holding “where a woman is employed on work which, not being work in relation to which (in respect of the man hereinafter mentioned) paragraph (a) or (b) above applies, is, in terms of the demands made on her (for instance under such headings as effort, skill and decision), of equal value to that of a man in the same employment".

17 Pickstone v Freemans Plc [1989] AC 66, 112. In Webb v Emo Air Cargo (U.K.) Ltd. (No. 2) [1995] 1 WLR 1454 (a pregnancy discrimination case), Lord Keith felt able to construe the Sex Discrimination Act 1975 so as to comply with the EC law, following a reference to the ECJ, in a very short and ambiguous speech. Unfortunately, the other Lords on that panel merely agreed. Given its brevity it will not be considered here beyond to say that while their lordships did not explain their reasoning in terms it would appear that they interpreted section 5(3) - which held that "A comparison of the cases of persons of different sex... must be such that the relevant circumstances in the one case are the same or not materially different, in the other" - as capable of being read as saying that if a dismissed woman was dismissed because she was pregnant, and as a man cannot be pregnant, therefore she must have been discriminated against because of her sex.

18 Pickstone v Freemans Plc [1989] AC 66, 112 and 128.

19 Council Directive 77/187/EEC.

${ }^{20}$ Litster and Others $v$ Forth Dry Dock \& Engineering Co. Ltd. (In Receivership) and Another [1990] 1 AC 546.
} 
order that the manifest purpose of the Regulations might be achieved and effect given to the clear but inadequately expressed intention of Parliament certain words must be read in by necessary implication. ${ }^{21}$

The words implied in Litster were to add "or would have been so employed if he had not been unfairly dismissed in the circumstances described in regulation 8(1)"22 following the regulation's reference to being "so employed immediately before the transfer". While the number of words inserted is not insignificant, it is a common sense decision and clearly gives effect to the underlying purpose-as Lord Keith put it, without the implication "a coach and four would have been driven through the provisions". ${ }^{23}$ It is not the number of words, but the underlying purpose which is the key issue; something which Lord Rodger noted some years later in his review of authorities in Ghaidan $v$ Godin-Mendoza. ${ }^{24}$ Expressly drawing an analogy with Housman's advice on the sound emendation of corrupt text, Lord Rodger considered that the key to what is legitimate lies in a careful consideration of the principles and scope of the legislation:

If the insertion of one word contradicts those principles or goes beyond the scope of the legislation, it amounts to impermissible amendment. On the other hand, if the implication of a dozen words leaves the essential principles and scope of the legislation intact but allows it to be read in a way which is compatible with Convention rights, the implication is a legitimate exercise... $^{25}$

While Ghaidan, a landlord and tenant case, involved the interpretative obligation under section 3(1) of the Human Rights Act 1998, the House of Lords treated the ECHR and EC situations as analogous ${ }^{26}$ and as the case is much cited in EBR Attridge Law LLP \& Anor v Coleman ${ }^{27}$ (considered in detail below) and other cases it makes sense to briefly outline the case here. In Ghaidan the courts were concerned with the interpretation of the word 'spouse' within provisions of the Rent Act 1977 dealing with statutory tenants by succession. While it could hardly be thought that the legislators intended to include homosexual partners within the provision back in

\footnotetext{
${ }^{21}$ Litster Others v Forth Dry Dock \& Engineering Co. Ltd. (In Receivership) and Another [1990] 1 AC $546,584$.

22 Litster Others v Forth Dry Dock \& Engineering Co. Ltd. (In Receivership) and Another [1990] 1 AC $546,577$.

23 Indeed the phrasing has come to be enshrined verbatim by Parliament in the successor regulations, Transfer of Undertakings (Protection of Employment) Regulations 2006/246 reg. 4(3).

24 Ghaidan v Godin-Mendoza [2004] 2 AC 557.

25 Ghaidan v Godin-Mendoza [2004] 2 AC 557 at [122].

26 See e.g. Ghaidan v Godin-Mendoza [2004] 2 AC 557 at [48], [118]. Ghaidan was applied by the CA in an EC context in HMRC v IDT Card Services Ireland Ltd [2006] EWCA Civ 29. For more on interpretation under the ECHR see, e.g., Marshall (2003) and Sales and Ekins (2011). Sales and Ekins hold that, in English law, the boundary between ECHR-compliant interpretation and when to make a declaration of incompatibility is the thing "which brings most acutely into focus the issue of the proper respective functions of the legislature and the courts" (at 217). This article contends that when and how to use indirect effect also brings the issue sharply into focus.
}

27 [2010] ICR 242. 
1977, it was nonetheless possible to read the term spouse so as not to conflict with Article 8 and 14 ECHR rights, not least, according to the leading speech of Lord Nicholls, given the history of changes to the provision (with widowers having been accorded a privileged position regarding succession in 1980 and the survivor of a cohabiting heterosexual couple being treated in the same way as a spouse of the original tenant from 1988). ${ }^{28}$ In the words of Lord Rodger, such an interpretation goes "with the grain" 29 of the Act as the underlying rationale is the same, it would not contradict any cardinal principle of the Act and it would reflect that society has moved on since the provision was last amended. ${ }^{30}$ In the somewhat more colourful language of Buxton LJ in the Court of Appeal, "Parliament having swallowed the camel of including unmarried partners within the protection given to married couples, it is not for this court to strain at the gnat of including such partners who are of the same sex as each other". ${ }^{31}$ In Ghaidan, no great insertion of words was necessary, it being arguably a fairly simple matter of interpretation in light of changing mores (with Baroness Hale declaring that it was "not even a marginal case"). ${ }^{32}$ This was not the case, however, in EBR Attridge Law LLP \& Anor $v$ Coleman, ${ }^{33}$ which saw an entire sub-section read, or written, in by the EAT.

\section{Extreme Judicial Drafting in EBR Attridge Law LLP \& Anor v Coleman}

Attridge Law revolved around the scope of both the Disability Discrimination Act 1995 (DDA) and Council Directive 2000/78/EC of 27 November 2000 establishing a general framework for equal treatment in employment and occupation. Ms Coleman started working for Attridge Law as a legal secretary in 2001. The following year she gave birth to a disabled son. (The disability, being the suffering of apnoeic attacks and congenital laryngomalacia and bronchomalacia, necessitated specialised and particular caring, with Ms Coleman being his principal carer.) On the assumed facts of the preliminary case, Ms Coleman was, inter alia, not allowed to return to the same position as she held before, was denied the same flexibility as regards working hours and conditions as offered to other parents (of non-disabled children), was described as lazy when she requested time off to care for her son (whereas other parents were allowed time off), was subject to abusive and insulting comments and was threatened with dismissal if she came to work late again because of her son's condition. She accepted voluntary redundancy in 2005 and then sought to bring a claim for disability discrimination, disability-related discrimination and disability harassment, her resignation having been a response to that treatment.

\footnotetext{
${ }^{28}$ Ghaidan v Godin-Mendoza [2004] 2 AC 557, [14]; Antonio Mendoza v Ahmad Raja Ghaidan [2002] EWCA Civ 1533 at [35] per Buxton LJ.

29 Ghaidan v Godin-Mendoza [2004] 2 AC 557 at [121]; the phrasing is cited with approval by Lord Nicholls at [33].

${ }^{30}$ Ghaidan v Godin-Mendoza [2004] 2 AC 557 at [128].

31 Antonio Mendoza v Ahmad Raja Ghaidan [2002] EWCA Civ 1533 at [35].

32 Ghaidan v Godin-Mendoza [2004] 2 AC 557 at [144].

33 Attridge Law LLP \& Anor v Coleman [2010] ICR 242.
} 
However, for all three claims the DDA used the claimant-specific formulation (as also used with regard to direct discrimination in the Sex Discrimination Act 1975 and the Employment Equality (Age) Regulations 2006) rather than the wider formulation adopted in the Race Relations Act 1976 and the other employment equality regulations which allowed for claims based on another's characteristic ('associative discrimination'). ${ }^{34}$ Thus under the express wording of the DDA the less favourable treatment or harassment needed to be related to, or on the grounds of, 'the disabled person's disability', and the complainant had to be that disabled person.

Whether or not Council Directive 2000/78/EC (the 'Framework Directive') extended to cover associative discrimination was not clear and the matter was referred to the ECJ by the tribunal, who duly decided that, while the directive did not directly address the matter, "an interpretation of Directive 2000/78 limiting its application only to people who are themselves disabled is liable to deprive that Directive of an important element of its effectiveness and to reduce the protection which it is intended to guarantee" (the underlying principles of the directive being concerned with recognising the worth of every individual, their ability to develop their sense of dignity and self-respect and their ability to exercise their autonomy). ${ }^{35}$ That interpretation of the directive was sufficient for Employment Judge Stacey, at the tribunal, to hold that the DDA could be interpreted so as to comply with European law through the insertion of such words as "or a person associated with a disabled person" whenever the relevant provisions (sections 3A, 3B and 4) referred to 'the disabled person'. On appeal to the EAT, Underhill P echoed both Lord Keith in Pickstone $e^{36}$ and Lord Nicholls in Ghaidan ${ }^{37}$ in stating that it is not necessary to draft precisely the implied words, but he nevertheless went on to do so. Rather than follow Employment Judge Stacey's more economical but flawed approach (which peculiarly referred to the abilities of the associated person rather than the disabled person when making the comparison necessary in a discrimination claim), he preferred to purport to insert two new sub-sections, s.3A(5A) and s.3B(3) (as well as make smaller amendments referring to those subsections) holding that with regard to direct discrimination, for example:

I would thus, if I were re-drafting the statute to give effect to the reasoning of the Court, add to s. 3A a sub-section (5A) in the following terms:

\footnotetext{
34 See e.g. Weathersfield Ltd v Sargent [1999] ICR 425, CA building on, inter alia, Race Relations Board $v$ Applin [1975] AC 259 in holding that less favourable treatment on 'racial grounds' need not involve the complainant's own race. The employment equality regulations are the Employment Equality (Religion or Belief) Regulations 2003-which expressly makes clear that the ground need not be the complainant'sand the Employment Equality (Sexual Orientation) Regulations 2003 which follows the principle in Weathersfield (English v Thomas Sanderson Ltd [2009] ICR 543, CA). For the sake of completeness, it should be noted that from its inception the Employment Equality (Age) Regulations 2006 adopted the associative approach with regard to harassment (as opposed to direct discrimination) as did the Sex Discrimination Act 1975 following an amendment in 2008.

35 Coleman v Attridge Law (Case C-303/06) [2008] 3 CMLR 27.

36 Pickstone v Freemans Plc [1989] AC 66, 112.

37 Ghaidan v Godin-Mendoza [2004] 2 AC 557 at [35].
} 
(5A) A person also directly discriminates against a person if he treats him less favourably than he treats or would treat another person by reason of the disability of another person....

(with s.3B(3) extending harassment in similar fashion). ${ }^{38}$

This formulation does not refer to, and arguably is not confined to, association, and in applying a general test goes much further than the ECJ's judgment which made it clear that their answer to the referred question specifically related to the cases of an employee who is the carer of a disabled child. ${ }^{39}$ While it may be going too far to describe this as 'judicial vandalism, 40 to an already much amended piece of legislation, as it does not negative an explicit provision, both the content and the format (in creating virtual new numbered subsections) appear to push the interpretative obligation to the limit and, indeed, towards horizontal direct effect. Unlike in Pickstone, there was no ambiguity; unlike Litster, this did not fill an otherwise absurd lacuna and unlike in Ghaidan it does not involve a straightforward interpretation in light of changing mores; instead it introduced a concept into the Act which was not intended by legislature or government (or, in terms, as was acknowledged by Underhill P, by the ECJ). Arden LJ has written that

Even if the court comes to the conclusion that [EU law] requires it to adopt its own conforming interpretation, that is, an interpretation which is not the natural interpretation but which is required to make the provision compatible with Convention rights or Community law, it may well find in the deeper layers of the legislation a seam of material to assist it. ${ }^{41}$

No such material existed in Attridge. The difference between 'spouse' and 'civil partner' is far smaller than that between the disability of the claimant and the disability 'of another person'. In Ghaidan the interpretation went 'with the grain of the Act', whereas in Attridge it inserted a new and distinct plank. The Marleasing obligation is to interpret national law, so far as possible, in the light of the wording and the purpose of the directive, ${ }^{42}$ but there must come a time when the text is strained so much that possible interpretation becomes judicial legislation.

Associative discrimination has been an accepted part of Race Discrimination in Britain since Showboat Entertainment Centre Ltd $v$ Owens [1984] ICR 65 and Weathersfield Ltd $v$ Sargent ${ }^{43}$ as well as being part of the newer grounds of sexual

\footnotetext{
38 EBR Attridge Law LLP \& Anor v Coleman [2010] ICR 242 at [15].

39 Coleman v Attridge Law (Case C-303/06) [2008] 3 CMLR 27 at [56].

${ }^{40}$ To adopt Lord Bingham's phrase in $R$ (on the app. of) $v$ Secretary of State for the Home Department [2002] UKHL 46 at [30] ("To read section 29 as precluding participation by the Home Secretary, if it were possible to do so, would not be judicial interpretation but judicial vandalism: it would give the section an effect quite different from that which Parliament intended and would go well beyond any interpretative process sanctioned by section 3 of the 1998 Act ...").

41 (Arden 2008, 507).

42 See also Pfeiffer (Social policy) [2004] ECR 8835. This case predated Kücükdeveci v Swedex GMBH [2010] IRLR 346 which, as is noted later, suggested that there could be judicial deletion of words which prevent a directive-compliant interpretation.
}

43 [1999] ICR 425, CA. 
orientation and religion or belief ${ }^{44}$ but, at that time, it had not been part of direct discrimination relating to sex, age or, hitherto, disability. Underhill $\mathrm{P}$, in forming his view, considered that the conclusion reached in the race cases of Showboat and Weathersfield "confirms that as a matter of UK law the policy underlying the antidiscrimination legislation applies to associative discrimination as much as to "primary" discrimination" and went on to state that he could "see no reason why there should be a different policy as regards disability discrimination and no reason to suppose that the choice to draft by reference to 'a disabled person' reflected a deliberate and different policy judgment". ${ }^{45}$ This ignores the fact that sex and age also adopted the claimant specific formulation and, indeed, that when the Employment Equality (Age) Regulations 2006 were laid the explanatory notes declared that the narrower approach as regards direct discrimination had been used deliberately. ${ }^{46}$ Furthermore, in the government's Discrimination Law Review, it was proposed to keep the then approach for both sex and age discrimination; in the case of the former because a change would be of no practical benefit and in the case of the latter because "[e]xtending the definition to include association could potentially bring in parents, carers, teachers, dependants and many others, taking the legislation far beyond its intended scope". 47 It was also proposed that disability discrimination should remain the same, since to introduce associative discrimination would "significantly extend the responsibilities of those with duties under the legislation" and be disproportionate, though they noted that the then pending ECJ decision in Attridge Law could require them to review the matter.

While all the foregoing is non-statutory, there is, furthermore, some legislative indication that the unambiguous wording in the Disability Discrimination Act 1995 was deliberately narrow, as can be seen in both section 4(5) of the pre-1st October 2004 version of the DDA 1995 and section 55(5) of the post-1st October 2004 version of the Act. These stated respectively (i) that "[i]n the case of an act which constitutes discrimination by virtue of section 55 [Victimisation], this section also applies to discrimination against a person who is not disabled" and (ii) that "[i]n the case of an act which constitutes discrimination by virtue of this section [section 55], sections $4,4 \mathrm{~B}, \ldots$ also apply to discrimination against a person who is not disabled". To hold that the phrase "disabled person" can include those associated with a disabled person is to render such sub-sections from whichever version utterly purposeless. Although Underhill P noted that Ms Coleman's claims related to acts or

\footnotetext{
44 By analogy with the Race Relations Act 1976 as regards Sexual Orientation and through explicit phrasing in the Religion or Belief Regulations.

45 EBR Attridge Law LLP \& Anor v Coleman [2010] ICR 242 at [14].

46 Employment Equality (Age) Regulations 2006 Notes on Regulations, para 9 (available online: http:// webarchive.nationalarchives.gov.uk/20060924231655/dti.gov.uk/files/file27136.pdf; accessed 30 April 2013). NB this is a different document to the Explanatory Memoranda to the Regulations which accompany the regulations on ww.legislation.gov.uk/uksi/2006/1031/made and which provide some background to policy rather than the notes' regulation-by-regulation commentary.

47 Dept of Communities and Local Government (2007).
} 
omissions after $1^{\text {st }}$ October 2004 and he recites section 55 among the relevant provisions, he does not include any reference to section $55(5) .^{48}$

In coming to his ultimate conclusion, Underhill $\mathrm{P}$ peremptorily dismissed the dicta (detailed below) of Burton $\mathrm{J}$ in Equal Opportunities Commission v Secretary of State for Trade and Industry ('EOC'), ${ }^{49}$ and the approval of it by Laws LJ in English $\mathrm{v}$ Thomas Sanderson Ltd, ${ }^{50}$ stating that those judgments "are no more than conclusions, right or wrong, on the particular problem in those cases: they do not add to the guidance to be found in Ghaidan". ${ }^{1}$ In EOC, Burton $\mathbf{J}$ had declined to interpret section 4A(1)(a) of the Sex Discrimination Act 1975, which read "on the ground of her sex, he engages in unwanted conduct that has the purpose or effect of violating..." as reading "he engages in unwanted conduct that has the purpose or effect on the ground of her sex of violating..." as he considered that to do so was not

appropriate - by virtue of the extent of reading down/transposition which would be required to be considered in order to render them compliant: or possible - because I am not persuaded that even such extreme application of the Marleasing principle would in any event be effective: or sensible because of the need for clarity and certainty, and comprehensibility, by employees and employers alike. ${ }^{52}$

Attridge Law could thus be seen to represent the high water mark of judicial interpretation given both the preceding cases discussed above and subsequent judgments of both the Scottish EAT (in Kulikaoskas $v$ MacDuff Shellfish \& Ors) ${ }^{53}$ and of the English and Welsh EAT (in the albeit contradictory cases of Rowstock $v$ Ltd $v$ Jessemey ${ }^{54}$ and Akwiwu \& Anor v Onu $)^{55}$ which are discussed below; as is the later appeal in Rowstock, where Underhill LJ has continued his practice of inserting subsections.

\section{Kulikaoskas v MacDuff Shellfish: Attridge Law Distinguished and Problems with the Equality Act 2010}

Kulikaoskas saw the question of associative discrimination move on to the characteristic of pregnancy/maternity. Ms Mihailova and Mr Kulikaoskas were partners and were employed by MacDuff Shellfish for less than a month before

\footnotetext{
48 EBR Attridge Law LLP \& Anor v Coleman [2010] ICR 242 at [4] (while s.55(1)-s.55(4) are laid out in that paragraph of the judgment there is no mention of s.55(5) or the predecessor s.4(5)).

49 Equal Opportunities Commission v Secretary of State for Trade and Industry [2007] IRLR 327.

50 English v Thomas Sanderson Ltd [2008] EWCA Civ 1421 at [33].

51 EBR Attridge Law LLP \& Anor v Coleman [2010] ICR 242 at [20].

52 Equal Opportunities Commission v Secretary of State for Trade and Industry [2007] IRLR 327 at [61].

53 [2011] ICR 48 (the case went to appeal to the Court of Session who referred a question on interpretation to the ECJ on January 30, 2012 (Case C-44/12; 2012/C 109/10) but this was withdrawn in November 2012 (2013/C 108/43).

54 Rowstock $v$ Ltd v Jessemey [2012] UKEAT 0112_12_0503 (05 March 2013).

55 Akwiwu \& Anor v Onu [2013] UKEAT 0283_12_0105 (1 May 2013).
} 
being dismissed and both brought claims for sex/pregnancy discrimination under the Sex Discrimination Act 1975. In his claim form, Mr Kulikaoskas stated that his partner's pregnancy was the cause for the less favourable treatment, the dismissal being a response to his informing his supervisor that she was pregnant when questioned as to why he was helping her lift heavy weights. The claim form was not accepted by the Employment Tribunal and he appealed to the EAT where Lady Smith, working on the assumption that Mr Kulikaoskas's statements were true, dismissed the appeal as a matter of law.

The provision subject to interpretation was section 3A(1) of the SDA 1975 which stated "a person discriminates against a woman if-(a) at a time [between becoming pregnant and the end of her maternity leave], and on the ground of the woman's pregnancy, the person treats her less favourably..." and it was common ground that on a plain reading the claimant had no case. The dispute was over whether European law required that plain reading to be subject to purposive interpretation or extension. Section 3A had been inserted into the SDA 1975 in an attempt to comply with the Equal Treatment Amendment Directive 2002/73/EC (regarding equality between men and women) although pregnancy had for some years already fallen within sex discrimination following a series of ECJ cases. ${ }^{56}$ The inserted section had been slightly recast in 2008, it having been found in a further strand of the EOC case that the new section impermissibly included a requirement for a comparator (a nonpregnant woman) contrary to both the directive and the pre-existing case law. ${ }^{57}$

The European derivation of the provision was thus clear but Lady Smith distinguished the case from that of Ms Coleman in both the ECJ and the subsequent EAT decision. The relevant directives in Kulikaoskas were the Equal Treatment Directives (ETD) ${ }^{58}$ and the Pregnant Workers Directive ${ }^{59}$ rather than the Framework Directive. While the Framework Directive was silent as to associative discrimination (although, as mentioned above, with underlying principles requiring it to be covered), the ETD provision was not only part of a 'separate code' — which rather than being concerned with issues of diminishing autonomy or general respect $^{60}$ sought to provide special support and protection for pregnancy and maternity_but its wording militates against associative discrimination; article 2(2) differentiating between 'persons' (for the broader sex-based claims) and 'a woman'

\footnotetext{
56 Dekker v Stichting Vormingscentrum voor Jonge Volwassen (VJV-Centrum) Plus [1991] IRLR 27, ECJ; Webb v EMO Air Cargo [1994] 2 CMLR 729; Tele Danmark A/S v Handels- og Kontorfunktionaerernes Forbund i Danmark (HK), acting on behalf of Brandt-Nielsen [2001] IRLR 853, ECJ. The abbreviation ECJ is used here as it was the predominant abbreviation for the court during the time of these cases; the court under the Treaty of Rome and the Treaty on European Union refer to the court as the Court of Justice, e.g. 'the Court of Justice of the European Union includes the Court of Justice, the General Court and specialised courts' (Article 19(1) of the EU Treaty).

57 Equal Opportunities Commission v Secretary of State for Trade and Industry [2007] IRLR 327 at [63]. Originally the extract from s.3A(1)(a) SDA 1975 quoted above continued "...than he would treat her had she not become pregnant". Counsel for the EOC preferred the EC's use of 'unfavourably' rather than less favourably (at [47]), and the Equality Act 2010 adopts that formulation (ss.17, 18).

58 Council Directives 76/207, 2002/73/EC, and 2006/54/EC.

59 Council Directive 92/85/EC.

${ }^{60}$ [2011] ICR 48 at [37], [38].
} 
(for pregnancy/maternity discrimination). ${ }^{61}$ Accordingly, Lady Smith declined to consider how far the ECJ or EAT decisions in Attridge could be extended, beyond potentially allowing someone other than a disabled person to claim disability discrimination, but did note the evident importance given by the ECJ to the fact that Ms Coleman was the primary carer (rather than mere association). ${ }^{62}$ She thus did not accept the Claimant's proposed 'insertion' of a new sub-section into section 3A SDA 1975 allowing associative discrimination ${ }^{63}$ and considered that were such an interpretation to be adopted it would be hard to see how, in two vivid examples, a priest dismissed on grounds of the pregnancy of a nun with whom he had a sexual relationship, or a teacher dismissed on grounds of the pregnancy of a pupil with whom he had a sexual relationship, could be excluded from having a claim. ${ }^{64}$ Lady Smith also declined counsel for the claimant's invocation of the Equality Act 2010 on grounds that the wording of the provisions "was not entirely clear and, further, there seemed to be no question of the statute having retrospective effect". ${ }^{65}$ Indeed, while pregnancy/maternity is now listed as one of the nine protected characteristics in section 4 of the Equality Act 2010 the drafting of the Act suggests that there may now be no direct discrimination claim for pregnancy/maternity let alone an associative one. Whilst the direct discrimination provision does not exclude any of the protected characteristics from its scope (unlike indirect discrimination and harassment which explicitly exclude pregnancy/maternity), a later sectionsection 25-does explicitly set out what is meant by the nine discriminations (for example "Age discrimination is-(a) discrimination within section 13 because of age; (b) discrimination within section 19 where the relevant protected characteristic is age") and for maternity/pregnancy discrimination it solely refers to the special provisions in sections 17 and 18 which expressly refer to the complainant in a clear contradistinction to the 'harmonised' direct discrimination provision.

\section{Victimisation and Further Problems with the Equality Act 2010}

Problems with the drafting and construction of the Equality Act 2010 were further to the fore in two cases where judgment was given within two months of each other, Rowstock Ltd $v$ Jessemey ${ }^{66}$ and Akwiwu \& Anor v Onu. ${ }^{67}$ Taking Rowstock first, the

\footnotetext{
${ }^{61}$ Lady Smith noted that "It would have been a simple matter to provide that discrimination covered any less favourable treatment of "persons in relation to a woman's pregnancy" if that was what had been intended", [2011] ICR 48 at [37].

${ }^{62}$ Kulikaoskas $v$ MacDuff Shellfish \& Ors [2011] ICR 48 at [19].

${ }^{63}$ Kulikaoskas v MacDuff Shellfish \& Ors [2011] ICR 48 at [24]: “(1A) A person also directly discriminates against a person if he treats him less favourably than he treats or would treat another person by reason of the pregnancy or maternity leave of another person."

64 Kulikaoskas v MacDuff Shellfish \& Ors [2011] ICR 48 at [34].

65 Kulikaoskas v MacDuff Shellfish \& Ors [2011] ICR 48 at [25].

66 Rowstock v Jessemey [2012] UKEAT 0112_12_0503.

67 Akwiwu \& Anorv Onu [2013] UKEAT 0283_12_0105. The facts of the case (exploitation of Nigerian migrant domestic worker) do not add anything to this discussion and predominantly relate to the separate question of the fundamental nature of direct and indirect discrimination, victimisation being a subsidiary
} 
facts were as follows. Mr Jessemey, a car repairer, had been dismissed by Rowstock around his 66th birthday as they did not wish to employ men over 65. They failed to comply with the (then) statutory retirement procedures and conceded the unfairness of the dismissal but Mr Jessemey also claimed compensation for post-employment victimisation due to a poor reference which he claimed was given due to his initiating tribunal proceedings. The Employment Tribunal accepted that the poor reference had been given because of the proceedings but found that they had no power to award a remedy given the wording of the victimisation provisions within the Equality Act 2010. He appealed to the EAT (which also heard a cross-appeal by Rowstock on a separate point concerning a reduction in damages).

It has been a matter of EU law since 1998 that victimisation (broadly speaking less favourable treatment suffered as a result of doing something in connection with discrimination legislation) could apply to things done after the end of the employment relationship. ${ }^{68}$ The House of Lords in 2003 accepted this point regarding both victimisation and other forms of harassment in Rhys-Harper $v$ Relaxion Group Plc ${ }^{69}$ and Parliament that year serially legislated for such posttermination events (in the Employment Equality (Religion or Belief) Regulations 2003, the Employment Equality (Sexual Orientation) Regulations 2003 and through amendments to the existing legislation). ${ }^{70}$ These provisions were replaced by section 108 of the Equality Act 2010. This 'similar' provision, to quote the Explanatory Notes, also extended the coverage to non-employment related religion or belief, sexual orientation and age discrimination. However, another novation is that in section 108(7) it explicitly states "But conduct is not a contravention of this section in so far as it also amounts to victimisation of B by A". Unless there was some other means allowing claims for post-employment victimisation, the UK would appear to be non-compliant with the EU law following a "legislative blunder" (in the words of Counsel) or the, highly likely unintentional, introduction of a lacuna (as found by the EAT). ${ }^{71}$ The complainant adopted the intervening Equality and Human Rights Commission's “particularly broad approach to the task of statutory construction and/or interpretation" to attempt to win his claim and render actual legislative amendment unnecessary, ${ }^{72}$ citing among other cases Attridge where Underhill P, in the words of the EAT, stepped "beyond the strict

\footnotetext{
Footnote 67 continued

point in the case. Indeed, it was heard alongside the appeal in Taiwo $v$ Olaigbe [2013] UKEAT 0254_12_0503 which was solely on this wider point and not the victimisation issue mentioned above.

68 Coote v Granada Hospitality Ltd (C-185/97) [1998] 3 CMLR 958; for more on the history of victimisation see Middlemiss (2013).

69 Rhys-Harper v Relaxion Group Plc [2003] UKHL 33.

70 S.27A Race Relations Act 1976 inserted by Reg. 29 Race Relations Act 1976 (Amendments) Regulations 2003, SI 2003/1626; S.20A Sex Discrimination Act 1975 inserted by Reg. 3 Sex Discrimination Act 1975 (Amendment) Regulations 2003, SI 2003/1657; S.16A Disability Discrimination Act 1995 inserted by Reg. 15 Disability Discrimination Act 1995 (Amendment) Regulations 2003 SI 2003/1673. These are inaccurately all cited to SI 2003/1673 in Rowstock ([2012] UKEAT 0112_12_0503 at [21]).

71 Rowstock v Jessemey [2012] UKEAT 0112_12_0503 at [26] and [29].

72 Rowstock $v$ Jessemey [2012] UKEAT 0112_12_0503 at [14] and [27].
} 
limits of domestic principles of statutory construction -in order to read words into legislation in order to achieve conformity with Community law". 73 The main authority, relied on by all sides, however, was Ghaidan.

As mentioned above, in his leading speech, Lord Nicholls stated that "[w]ords implied must, in the phrase of my noble and learned friend Lord Rodger of Earlsferry, 'go with the grain of the legislation", His lordship continued " $[\mathrm{t}]$ here may be several ways of making a provision Convention-compliant, and the choice may involve issues calling for legislative deliberation". ${ }^{74}$ The EAT eschewed the approach taken by Employment Judge Tsamados (sitting alone) in Taiwo $v$ Olagigbe $^{75}$ as defining employment as including 'current and/or former' employment when interpreting the Equality Act 2010 as to follow such a "tempting" approach would lead to an incomplete recasting of the Act as section 108 applies to many other relationships (such as the provision of goods and services but also such more analogous relationships as partners, contract workers, etc.). ${ }^{76}$ Furthermore, the presence of an express exception in section 108(7), meant that in Rowstock "no judicial tool is available to make available a remedy which the words used by Parliament have simply stated shall not be available". ${ }^{77}$ Indeed, in stark contradistinction to Rhys-Harper $v$ Relaxion Group Plc where the courts could extrapolate remedies to fill an unconsidered point, in Rowstock the EAT were "being invited to hold that [section 108(7)] means the exact reverse of what it says" and they unanimously refused to read "is not" as meaning "is also". ${ }^{78}$ Citing Ghaidan, they refused to cross the "Rubicon which the courts may not cross" (per Lord Steyn at [49]). While Underhill P in Attridge found a pathway illuminated by Ghaidan which allowed an EU law compliant result, the EAT with the advantage of a full tribunal found themselves "unable to hold that the pathway can be followed by us to produce such a result in the instant case". ${ }^{79}$

\footnotetext{
73 Rowstock v Jessemey [2012] UKEAT 0112_12_0503 at [32]; Kücükdeveci v Swedex GMBH [2010] IRLR 346 was also noted.

74 Ghaidan v Godin-Mendoza [2004] 2 AC 557 at [33].

75 Taiwo $v$ Olagigbe unreported (ET case number 2389629/2011).

76 Rowstock v Jessemey [2012] UKEAT 0112_12_0503 at [34].

77 Rowstock [2012] UKEAT 0112_12_0503 at [39].

78 Rowstock v Jessemey [2012] UKEAT 0112_12_0503 at [36]-[38]. Kavannagh (2009) criticises Ewing and Tham (2008) in another context for, in her words, holding the view that if "courts interpret statutory wording in a way which departs from what those words are 'thought to mean in ordinary standard language', they must be guilty of arbitrary linguistic manipulation of Humpty Dumpty proportions' and reminds us that purposive interpretation enjoins courts to depart from ordinary meanings to advance the purpose (at 297). However, this case at least cannot be held to such a charge as to hold words as meaning the direct opposite surely goes beyond interpretation and into the world of Lewis Carroll.

79 Rowstock $v$ Jessemey [2012] UKEAT 0112_12_0503 at [38]. While there was a mistake in the Act, the express contradictory wording would mean that any remedy should be sought against the government under Francovich rather than the ex-employers (see also Burton J Equal Opportunities Commission $v$ Secretary of State for Trade and Industry [2007] IRLR 327 regarding the importance of clarity, certainty and comprehensibility for employees and employers, at [61].
} 
Two months later, in Akwiwu \& Anor $v$ Onu, ${ }^{80}$ an EAT led by Langstaff P (and with one common member) disagreed with the decision in Rowstock primarily as a matter of national law. While they were "troubled by both the exact meaning and purpose of Subsection (7)" and noted that the "provision is not explicit" and litotically "not entirely easy to discern", 81 they concluded that section 108(7) could only make sense if the draftsman had assumed that there could be some other way that post-termination victimisation could be subject to a claim (as otherwise the restriction would serve no purpose).$^{82}$ In doing so, they dismissed the proposition that 'insofar as it also' could be taken to mean 'furthermore' and thus act as an express exclusion of victimisation from being compensable post-termination (as interpreted in Rowstock). Instead, they considered that it had to be read as saying that if there is victimisation present then there is no claim for harassment or discrimination under this section with any claim being recoverable under a separate victimisation provision and the section thus prevents double recovery. The fact that there is no separate victimisation provision caused them to invoke Rhys-Harper and declare that the reasoning there applied to the definition of employee for victimisation purposes nothwithstanding that the section effectively codified Rhys-Harper for discrimination and harassment. ${ }^{83}$

This disparate treatment of the various types of claim caused the Tribunal "some hesitation" but they decided that their lacuna would be much smaller than that left by the other interpretation. ${ }^{84}$ There was, however, no consideration of the concern regarding incomplete recasting raised in Rowstock mentioned above. While not needing to use it as an interpretative aid, the EAT in Akwiwu drew comfort from the Equality and Human Rights Commission Code of Practice on Employment, which held that post-termination victimisation would be covered under the victimisation provisions (although it wrongly references readers to the definition rather than the prohibited act). ${ }^{85}$ However, unlike as in Rowstock, that EAT did not have the advantage of written and oral submissions on behalf of the Commission itself,

\footnotetext{
${ }^{80}$ Akwiwu \& Anor v Onu [2013] UKEAT 0283_12_0105. The facts of the case (exploitation of Nigerian migrant domestic worker) do not add anything to this discussion and predominantly relate to the separate question of the fundamental nature of direct and indirect discrimination, victimisation being a subsidiary point in the case. Indeed, it was heard alongside the appeal in Taiwo $v$ Olaigbe [2013] UKEAT 0254_12_0503 which was solely on this wider point and not the victimisation issue mentioned above.

81 Akwiwu \& Anorv Опи [2013] UKEAT 0283_12_0105 at [73], [83] and [75] respectively.

82 Akwiwu \& Anor v Onu [2013] UKEAT 0283_12_0105 at [76]-[77], [81]; the case is further complicated by the original 'protected act', giving rise to the victimisation claim, was done under the Race Relations Act 1976. If the victimisation claim had fallen under the old Act there would have been no debate but as the victimising occurred within the first few months of the Equality Act it applied by virtue of Art.8 of The Equality Act 2010 (Commencement No. 4, Savings, Consequential, Transitional, Transitory and Incidental Provisions and Revocation) Order 2010.

83 Akwiwu \& Anor v Onu [2013] UKEAT 0283_12_0105 at [87]-[94].

84 Akwiwu \& Anorv Onu [2013] UKEAT 0283_12_0105 at [95].

85 Akwiwu \& Anor v Onu [2013] UKEAT 0283_12_0105 at [97]. The Explanatory Notes to the Equality Act 2010 similarly holds with regard to s.108 that "if the treatment which is being challenged constitutes victimisation, it will be dealt with under the victimisation provisions and not under this section" (para 353). In the appeal in Rowstock, Underhill LJ doubted the admissibility of the code but noted the weight of the explanatory notes ([2014] ICR 550, note 5).
} 
submissions which in Rowstock were described as "a tour de force [which] amply developed every aspect of the point that could possibly have been deployed in support of the [unsuccessful] appeal". ${ }^{86}$ Given their views on national interpretation, the EAT in Akwiwu found that there was no need to resort to the European obligation but in five short paragraphs concluded that even if they were wrong on the national interpretation, the ambiguity would allow a Marleasing purposive approach (the purpose being to prohibit discrimination in many contexts). ${ }^{87}$ Such an interpretation-peremptorily dismissing the consideration in Rowstock but noting both the difficulty and that the argument put forward in the cases differednevertheless, on its own terms, does not go as far as that taken in Attridge.

When Rowstock went to the Court of Appeal, Underhill LJ, giving the judgment of the court, relied on Marleasing to overrule the EAT (and, in contrast to Akwiwu, he sought to use national law as a secondary device). Both EATs and the Court of Appeal were in agreement that a drafting error was the cause of the problem, but the EAT in Rowstock were unwilling to ignore an express provision, however accidental. Underhill LJ overcame this by holding that the 'decidedly opaque' section did not preclude an implication, remarking that should any future party seek to rely on it 'some other court can cudgel its brains about what real effect, if any, it has' ${ }^{88}$ This was supported by national law concerning rectification where there had plainly been a drafting error, ${ }^{89}$ which allows reading in of words in strict circumstances: i) where the intended purpose is clear; ii) the draftsman and parliament inadvertently failed to give effect to that purpose and iii) the court could be sure about the substance (if not the precise words) of the provision Parliament would have made had the error been noticed. As noted by the House of Lords, '[t]he third of these conditions is of crucial importance... Otherwise any attempt to determine the meaning of the enactment would cross the boundary between construction and legislation'. ${ }^{90}$ Neither the Court of Appeal in Rowstock nor the EAT in $A k$ wiwu considered the effect of the ECJ's decision in Kücükdeveci $v$ Swedex $G M B H^{91}$ which could have provided authority to disapply measures which conflict with a general principle of EU law (only the EAT in Rowstock mentioned the case). ${ }^{92}$ Even if they had, the implication concerning post-employment victimisation in the cases-which could be holding that victimisation fell within discrimination for the purposes of s.108 or to quote Underhill LJ 'more elaborately

\footnotetext{
${ }^{86}$ Rowstock $v$ Jessemey [2012] UKEAT 0112_12_0503 at [14].

87 Akwiwu \& Anor v Опи [2013] UKEAT 0283_12_0105 at [101]-[105].

88 Jessemey $v$ Rowstock Ltd \& Anor [2014] ICR 550, [45]-[49].

89 Inco Europe v First Choice Distribution [2000] 1 WLR 586.

90 Inco Europe v First Choice Distribution [2000] 1 WLR 586, 592.

91 [2010] IRLR 346.

92 Lord Mance, in $R$ (Chester) v Secretary of State for Justice [2013] UKSC 63, preferred the phrasing 'discontinue, disregard or set aside measures' where general principles of EU law were in play [61]-[62]. The nature and effects of Kücükdeveci were and are not clear (see e.g. Pears (2010); Clayton and Murphy (2014); Frantziou (2014)); but it is likely to have disapplying effect rather than inserting new law (disapplication was accepted in principle by Langstaff $\mathrm{J}$ in Innospec Ltd \& Ors v Walker [2014] ICR 645 [58]-[59] but not applied as, at the material time, the right in question did not fall within the scope of EU law).
} 
by a new sub-section (2A) which follows the form of sub-sections (1) or (2) but refers to victimisation rather than discrimination/harassment'- is less extreme than that performed in Attridge given the accepted drafting error. In any case, it leaves the legislation in an unsatisfactory state.

\section{Conclusion}

There is a clear divergence of practice among judges in discrimination cases as to the extent of the obligation to interpret, with Underhill LJ showing a tendency to insert subsections and having, in Attridge, seemingly pushed the obligation to breaking point and on to judicial legislation. It is a far cry from reading in a phrase to prevent a provision from being easily evadable as in in Litster to the reading in of a discrete concept against the intention of Parliament. Burton $\mathbf{J}$ and Laws LJ, beforehand, declined to go so far (and were lightly dismissed in Attridge) and subsequent cases, including those heard by Lady Smith (now President of Scottish Tribunals) and Underhill LJ himself, have taken a less radical approach, in the latter case in content if not in form.

While it is often clearly appropriate and efficient for national courts to interpret law to achieve an EU-compliant construction, there is, as illustrated by recent cases, a line beyond which it is better, more comprehensible and more comprehensive for compliance to be achieved through legislative action (and possibly Commission intervention ${ }^{93}$ ) than through juridicial contortion.

Open Access This article is distributed under the terms of the Creative Commons Attribution 4.0 International License (http://creativecommons.org/licenses/by/4.0/), which permits unrestricted use, distribution, and reproduction in any medium, provided you give appropriate credit to the original author(s) and the source, provide a link to the Creative Commons license, and indicate if changes were made.

\section{References}

Arden, M. 2008. The changing judicial role: human rights, Community law and the intention of Parliament. Cambridge Law Journal 67(3): 487.

Clayton, R and C. Murphy. 2014. The emergence of the EU Charter of Fundamental Rights in United Kingdom Law. European Human Rights Law Review (forthcoming) (available at ssrn.com/ abstract=2479611).

Craig, P., and G. de Búrca. 2011. EU law: Text, cases, and materials, 5th ed. London: OUP.

Dept of Communities and Local Government. 2007. Discrimination Law Review: A. Framework for Fairness: Proposals for a Single Equality Bill for Great Britain-A consultation paper. London.

Drake, S. 2005. Twenty Years after 'Von Colson': The Impact of 'Indirect Effect' on the Protection of the Individual's Community Rights. European Law Review 30: 329.

Frantziou, E. 2014. Association de mediation sociale: some reflections on the horizontal effect of the Charter and the reach of fundamental employment rights in the European Union. European Constitutional Law Review 10(2): 322.

Kavanagh, A. 2009. Judging the judges under the Human Rights Act: Deference, disillusionment and the "war on terror". Public Law 2: 287-304.

\footnotetext{
93 Which would, indeed, lead to amending legislation-as would any sui generis tortious claim against the state for failure to properly implement EU directives under Francovich [1995] ICR 722.
} 
Lester, A. 1993. English judges as law makers. Public Law 2: 269-290.

Marshall, G. 2003. The lynchpin of parliamentary intention: lost, stolen or strained? Public Law 2: 236-248.

Middlemiss, S. 2013. Employers liability for employee references and victimisation. Statute Law Review 34(2): 138.

Pears, S. 2010. Supremacy, equality and human rights: comment on Kucukdeveci (C-555/07). European Law Review 35(6): 849.

Sales, P., and R. Ekins. 2011. Rights-consisalrsent interpretation and the Human Rights Act 1998. Law Quarterly Review 127: 217.

Steiner, J., and L. Woods. 2009. EU law, 10th ed. London: OUP.

Twigg-Flesner, C. 2008. The Europeanisation of contract law. London: Routledge. 